\title{
A Plasmid-Transposon Hybrid Mutagenesis System Effective in a Broad Range of Enterobacteria
}

\section{OPEN ACCESS}

Edited by:

Trevor Carlos Charles,

University of Waterloo, Canada

Reviewed by:

Charles Martin Dozois,

Institut National de la Recherche

Scientifique, Canada

Hilary G. Morrison,

Marine Biological Laboratory, USA

*Correspondence:

George P. C. Salmona

gpcs2@cam.ac.uk

${ }^{\dagger}$ Present Address:

Debra S. Smith,

Guy's and St. Thomas' NHS Foundation Trust, Guy's Hospital,

London, UK;

Miguel A. Matilla

Department of Environmental

Protection, Estación Experimental del

Zaidín, Consejo Superior de

Investigaciones Científicas,

Granada, Spain;

Kevin Roberts,

VHsquared Ltd., Wellcome Trust

Sanger Institute, Hinxton, UK;

Elizabeth Richardson,

Department of Cell Biology, University of Alberta, Edmonton, AB, Canada;

Josh Ramsay,

Faculty of Health Sciences, Curtin Health Innovation Research Institute

Biosciences Precinct, Curtin

University, Bentley, WA, Australia

Specialty section:

This article was submitted to

Systems Microbiology,

a section of the journal

Frontiers in Microbiology

Received: 06 October 2015 Accepted: 03 December 2015 Published: 22 December 2015

\begin{abstract}
Rita Monson, Debra S. Smith ${ }^{\dagger}$, Miguel A. Matilla ${ }^{\dagger}$, Kevin Roberts ${ }^{\dagger}$, Elizabeth Richardson ${ }^{\dagger}$, Alison Drew, Neil Williamson, Josh Ramsay ${ }^{\dagger}$, Martin Welch and George P. C. Salmond *
\end{abstract}

Department of Biochemistry, University of Cambridge, Cambridge, UK

Random transposon mutagenesis is a powerful technique used to generate libraries of genetic insertions in many different bacterial strains. Here we develop a system facilitating random transposon mutagenesis in a range of different Gram-negative bacterial strains, including Pectobacterium atrosepticum, Citrobacter rodentium, Serratia sp. ATCC39006, Serratia plymuthica, Dickeya dadantii, and many more. Transposon mutagenesis was optimized in each of these strains and three studies are presented to show the efficacy of this system. Firstly, the important agricultural pathogen $D$. dadantii was mutagenized. Two mutants that showed reduced protease production and one mutant producing the previously cryptic pigment, indigoidine, were identified and characterized. Secondly, the enterobacterium, Serratia sp. ATCC39006 was mutagenized and mutants incapable of producing gas vesicles, proteinaceous intracellular organelles, were identified. One of these contained a $\beta$-galactosidase transcriptional fusion within the gene gvpA1, essential for gas vesicle production. Finally, the system was used to mutate the biosynthetic gene clusters of the antifungal, anti-oomycete and anticancer polyketide, oocydin A, in the plant-associated enterobacterium, Dickeya solani MK10. The mutagenesis system was developed to allow easy identification of transposon insertion sites by sequencing, after facile generation of a replicon encompassing the transposon and adjacent DNA, post-excision. Furthermore, the system can also create transcriptional fusions with either $\beta$-galactosidase or $\beta$-glucuronidase as reporters, and exploits a variety of drug resistance markers so that multiple selectable fusions can be generated in a single strain. This system of various transposons has wide utility and can be combined in many different ways.

Keywords: plasposon, transposon mutagenesis, Enterobacteria, Dickeya, Serratia, plant pathogen, gas vesicles, oocydin A

\section{INTRODUCTION}

Since their initial discovery, transposable elements have greatly assisted our understanding of eukaryotic and prokaryotic genetics. Though transposable elements were first identified and studied in maize, they have been found in virtually all organisms, such as Drosophila melanogaster, Escherichia coli, and Homo sapiens (McClintock, 1956; Craig, 1990; Frost et al., 2005; Cordaux and Batzer, 2009). Transposons in bacteria can also move from the chromosome to a plasmid 
or bacteriophage genome, driving genetic evolution and contributing to the spread of antibiotic resistance gene clusters between different bacteria (Jimenez and Davies, 1980; Berg and Berg, 1983).

Advances in molecular genetics and gene cloning have allowed development of genetic tools derived from mobile elements. For example, engineered mobile elements (transposons) have been used in genetic analysis to generate random insertions within the chromosome of a target organism (Berg and Berg, 1983) and insertion of a transposon near, or within, a gene can alter or destroy its function.

Transposons can jump between any genetic elements in their bacterial hosts: chromosome, plasmids or phage genomes (Berg and Berg, 1983). The insertion or excision of a transposon is facilitated by a transposase protein, which is usually encoded within the transposon itself. However, when expression of the transposase protein is decoupled from the transposon, a system can be engineered to generate immobile single transposon insertions in target DNA of interest.

Here we describe the creation of a type of transposon system that has a broad host range within the Enterobacteria that complements existing systems (Dennis and Zylstra, 1998; Larsen et al., 2002). This plasmid-transposon (or plasposon) hybrid system, has been engineered so that it carries an origin of replication, and so, can form a replicating plasmid if excised and self-ligated. Such a plasmid can be sequenced and the transposon insertion site identified with ease. We also used a second method to identify the transposon insertion sites, which relied upon Random Primed PCR (RP-PCR; Jacobs et al., 2003; Fineran et al., 2005). These two parallel methods facilitate quick and straightforward identification of any transposon insertion within a host's genome.

Three test studies were conducted to demonstrate the efficacy of this system. Firstly, the plasposon system described above was used to mutagenise the plant pathogen Dickeya dadantii, a cause of soft rot in many different plant species and a pathogen of the aphid Acyrthosiphon pisum (Grenier et al., 2006). Secondly, the system was used to create stable transcriptional fusions within gvpA1, the first gene in the gas vesicle operon of Serratia sp. 39006 (S39006). Thirdly, transposon mutants interrupting the oocydin A biosynthetic gene clusters in Dickeya solani MK10 were isolated-one of them generating a transcriptional fusion within the large oocJ-W operon. Together, these three studies demonstrate the wide utility of this system for genetic screens in a broad range of bacterial species.

\section{MATERIALS AND METHODS}

\section{Bacterial Strains, Plasmids, and Growth Conditions}

A list of the bacterial, fungal and bacteriophage strains and plasmids used in this study can be found in Table 1. All strains were grown in Luria Broth (LB; $5 \mathrm{~g} \mathrm{l}^{-1}$ yeast extract, $10 \mathrm{~g} \mathrm{l}^{-1}$ tryptone and $5 \mathrm{~g} \mathrm{l}^{-1} \mathrm{NaCl}$ ) in liquid culture (either in $30 \mathrm{~mL}$ sealed plastic universal tubes (Thermo Scientific Cat No 128A/P) on a rotary wheel or with shaking at $200 \mathrm{rpm}$ ) or on solid LB supplemented with $1.5 \%$ agar (LBA) unless otherwise indicated. E. coli strains were grown at $37^{\circ} \mathrm{C}$ with antibiotic supplements where indicated. All other strains were grown at $30^{\circ} \mathrm{C}$. Where indicated, $D$. dadantii was grown in PMB Medium $(0.1 \%(\mathrm{w} / \mathrm{v})$ yeast extract, $0.1 \%\left(\mathrm{NH}_{4}\right)_{2} \mathrm{SO}_{4}, 1 \mathrm{mM} \mathrm{MgSO}_{4}, 0.5 \%$ glycerol, $0.5 \%$ polygalacturonic acid, $\left.7 \mathrm{~g} \mathrm{l}^{-1} \mathrm{~K}_{2} \mathrm{HPO}_{4}, 2 \mathrm{~g} \mathrm{l}^{-1} \mathrm{KH}_{2} \mathrm{PO}_{4}\right)$, or iron-limiting MM9 Medium $\left(0.3 \mathrm{~g} \mathrm{l}^{-1} \mathrm{KH}_{2} \mathrm{PO}_{4}, 0.5 \mathrm{~g} \mathrm{l}^{-1} \mathrm{NaCl}\right.$, $1.0 \mathrm{~g} \mathrm{l}^{-1} \mathrm{NH}_{4} \mathrm{Cl}, 6.0 \mathrm{~g} \mathrm{l}^{-1} \mathrm{NaOH}$, and $30.24 \mathrm{gl}^{-1}$ PIPES). Bacterial culture optical density $\left(\mathrm{OD}_{600 \mathrm{~nm}}\right)$ was measured using a Unicam $\mathrm{He} \lambda$ ios Spectrophotometer. Antibiotics and supplements were added at the following concentrations: ampicillin, $100 \mu \mathrm{g}$ $\mathrm{ml}^{-1}$; chloramphenicol, $50 \mu \mathrm{g} \mathrm{ml}^{-1}$; tetracycline, $15 \mu \mathrm{g} \mathrm{ml}^{-1}$; kanamycin, $15 \mu \mathrm{g} \mathrm{ml}^{-1}$ (E. coli strain $\beta 2163$ ) and $50 \mu \mathrm{g} \mathrm{ml}^{-1}$ (S. plymuthica A153, D. solani MK10 and S39006); erythromycin, $200 \mu \mathrm{g} \mathrm{ml}^{-1}$, and 2-6-diaminopimelic acid (DAPA), $300 \mu \mathrm{M}$.

\section{DNA Manipulations, Oligonucleotides, and Sequencing}

Unless otherwise stated, standard molecular biological methods were used for all DNA manipulations. Plasmid DNA was extracted using a Qiagen Miniprep Kit (Qiagen) or an Anachem Keyprep Kit (Anachem) according to the manufacturer's instructions. Where required, DNA was extracted from individual strains using a Qiagen DNeasy Kit according to manufacturer's instructions. All restriction enzymes used were obtained from New England Biolabs and used according to manufacturer's protocols. DNA fragments were ligated using T4 DNA ligase (NEB). Oligonucleotides were obtained from Sigma Aldrich and are listed in Table 2. DNA sequencing was conducted in the Department of Biochemistry Sequencing Facility, University of Cambridge, Cambridge, United Kingdom.

\section{Cloning of pDS1028 and pKRCPN1}

The plasmid pBM1001 was created by insertion of the $\mathrm{XmnI} / \mathrm{BstBI}$ fragment from pACYC184 (containing the aph gene) into pBluescript II KS+. The plasmid pBM1002 was created by insertion of the StyI/XbaI fragment from pACYC184 (containing the tetA gene) into pBluescript II KS+. The plasmid pDS1028 was created in three steps. Firstly, the XbaI/EcoRI fragment containing the tetracycline resistance gene (tet $A$ ) from pBM1002 was ligated into pRL27 to create plasmid pDS1017. Secondly, pDS1017 was digested with SacI and pBM1001 was digested with AccI to remove the cat gene. Both fragments of DNA were treated to create blunt ends and were ligated together to create pDS1022. Finally, oligonucleotides $5^{\prime} \Omega$ PAC and $3^{\prime} \Omega E R V$ were used to amplify the $\Omega$ transcriptional and translational terminator from $\mathrm{pHP} 45 \Omega$, then this fragment was digested with EcoRV/PacI, and ligated into pDS1022 that had been compatibly digested, to create plasmid pDS1028.

The plasmid pKRCPN1 was created by modifying pDS1028. The promoterless lacZ1 fragment from miniTn5lacZ1 was ligated into the KpnI site of pDS1028, to create pNRW112. Oligonucleotide pair KR19/KR21 were used to amplify the aph gene from pACYC177. This was digested with BstBI and PacI and ligated into compatible sites of digested pNRW112 to create pKRCPN1. 
TABLE 1 | Strains and plasmids used in this study.

\begin{tabular}{|c|c|c|}
\hline Bacterial strains & Genotype & References or source \\
\hline Agrobacterium tumefaciens & Wild type & GPCS Lab Strain Collection \\
\hline Bacillus subtilis sp 168 & Wild type & GPCS Lab Strain Collection \\
\hline Citrobacter freundii & Wild type & GPCS Lab Strain Collection \\
\hline Citrobacter rodentium & Wild type & GPCS Lab Strain Collection \\
\hline D. dadantii 3937, REM392 & 3937 transposon mutant vfmE::Tn-DS1028 cat & This study \\
\hline D. dadantii 3937, REM393 & 3937 transposon mutant pecS::Tn-DS1028 cat & This study \\
\hline D. dadantii 3937, REM394 & 3937 transposon mutant vfmA::Tn-DS1028 cat & This study \\
\hline Dickeya solani MK10 & Wild type & JHI Strain Collection \\
\hline D. solani MK10, MK10oocG & $\begin{array}{l}\text { MK10 transposon mutant oocG::Tn-KRCPN1; oocydin A } \\
\text { negative, } \mathrm{Km}^{\mathrm{r}}\end{array}$ & This study \\
\hline Enwinia wasabiae & Wild type & JHI Strain Collection \\
\hline Escherichia coli CC118גpir & $\begin{array}{l}\Delta(\text { ara-leu) araD } \Delta \text { lacX74 galE galK phoA20 thi-1 rpsE rpoB } \\
\operatorname{argE}(\mathrm{Am}) \text { recA1 } \lambda \text { pir }\end{array}$ & Herrero et al., 1990 \\
\hline Escherichia coli DH5 $\alpha$ & $\begin{array}{l}\mathrm{F}^{-} \phi 80 / a c Z \Delta \mathrm{M} 15 \Delta(\text { lacZYA-argF) U169 recA1 endA1 } \\
\left.\text { hsdR17( } \mathrm{r}_{\mathrm{K}}^{-} \mathrm{m}_{\mathrm{K}}^{+}\right) \text {phoA supE44 } \lambda^{-} \text {thi-1 relA1 gyrA96 }\end{array}$ & Invitrogen \\
\hline Escherichia coli $\beta 2163$ & $\mathrm{~F}^{-}$RP4-2-Tc::Mu $\Delta$ dapA::(erm-pir) & Demarre et al., 2005 \\
\hline Pectobacterium atrosepticum SCRI1043 & Wild type & GPCS Lab Strain Collection \\
\hline Pectobacterium brasiliensis & Wild type & JHI Strain Collection \\
\hline Pectobacterium carotovorum sp ATCC39048 & Wild type & GPCS Lab Strain Collection \\
\hline Serratia marcescens sp.12 & Wild type & GPCS Lab Strain Collection \\
\hline S. plymuthica MMnO9 & A153 transposon mutant oocN::Tn-KRCPN1; $\mathrm{Km}^{r}$ & Matilla et al., 2012 \\
\hline S. plymuthica MMnO13 & A153 transposon mutant oocJ::Tn-KRCPN1; Km ${ }^{r}$ & Matilla et al., 2012 \\
\hline S. plymuthica MMnO14 & A153 transposon mutant oocC::Tn-KRCPN1; $\mathrm{Km}^{r}$ & Matilla et al., 2012 \\
\hline S. plymuthica MMnO15 & A153 transposon mutant oocU::Tn-KRCPN1; $\mathrm{Km}^{r}$ & Matilla et al., 2012 \\
\hline \multicolumn{3}{|l|}{ FUNGI/OOMYCETE STRAINS } \\
\hline Pythium ultimum & Wild type, plant pathogen & C. A. Gilligan \\
\hline Verticillium dahliae 5368 & Wild type, plant pathogen & R. Cooper \\
\hline \multicolumn{3}{|l|}{ PHAGES } \\
\hline$\varphi \times F 3$ & Generalized transducing phage for Dickeya solani & Matilla et al., 2014 \\
\hline$\varphi$ MAM1 & Generalized transducing phage for S. plymuthica A153 & Matilla and Salmond, 2014 \\
\hline$\varphi$ ОТ8 & Generalized transducing phage for S39006 & Evans et al., 2010 \\
\hline \multicolumn{3}{|l|}{ PLASMIDS } \\
\hline pACYC184 & cat, tetA & NEB \\
\hline pBluescriptllKS+ & bla, lacZ & Agilent \\
\hline pDS1028 & tetA, tnp, oriR6K, cat & This study \\
\hline pKRCPN1 & tetA, tnp, 'lacZ, oriR6K, aph & This study \\
\hline pBM1001 & cat, lacZ & This study \\
\hline
\end{tabular}


TABLE 1 | Continued

\begin{tabular}{|c|c|c|}
\hline Bacterial strains & Genotype & References or source \\
\hline pBM1002 & tetA, lacZ & This study \\
\hline pACYC177 & aph, bla & New England Biolabs \\
\hline $\mathrm{pHP} 45 \Omega$ & aph, bla & Prentki and Krisch, 1984 \\
\hline pRL27 & aph, oriT, oriR6K, tnp, tet $A p$ & Larsen et al., 2002 \\
\hline
\end{tabular}

TABLE 2 | Oligonucleotides used in this study.

\begin{tabular}{|c|c|c|}
\hline Name & Sequence $\left(5^{\prime}-3^{\prime}\right)$ & Notes \\
\hline oMAMV1 & GGAATTGATCCGGTGGATG & Sequencing primer pKRCPN1 \\
\hline oMAMV2 & GCATAAAGCTTGCTCAATCAATCAC & Sequencing primer pKRCPN1 \\
\hline oREM7 & CTAGAGTCGACCTGCAGGC & Sequencing primer pDS1028 \\
\hline oREM8 & CACAGGAACACTTAACGGC & Sequencing primer pDS1028 \\
\hline oPF106 & GACCACACGTCGACTAGTGCNNNNNNNNNNAGAG & Random prime PCR primer 1 \\
\hline oPF107 & GACCACACGTCGACTAGTGCNNNNNNNNNNACGCC & Random prime PCR primer 2 \\
\hline oPF108 & GACCACACGTCGACTAGTGCNNNNNNNNNNGATAC & Random prime PCR primer 3 \\
\hline oPF109 & GACCACACGTCGACTAGTGC & Random prime adaptor primer \\
\hline $5^{\prime} \Omega \mathrm{PAC}$ & CCСTTAATTAACCGCGAGCTTGGCAC & Amplification of $\Omega$ fragment forward \\
\hline $3^{\prime} \Omega$ ERV & CCCGATATCGCGCGAGGCAGAAGC & Amplification of $\Omega$ fragment reverse \\
\hline
\end{tabular}

\section{Transposon Mutagenesis}

Overnight cultures of each recipient strain and the E. coli donor strain were grown at $30^{\circ} \mathrm{C}$ and $37^{\circ} \mathrm{C}$, respectively. The donor and recipient strains were mixed together in the ratio indicated. The most efficient ratio for transposon mutagenesis for most strains was 1:3 (donor: recipient). Thirty microlitres of this mixture was spotted onto LBA + DAPA where required, and allowed to dry. The mixture was incubated overnight at $30^{\circ} \mathrm{C}$ and the mixed culture then resuspended in $1 \mathrm{ml}$ of sterile LB. The conjugation mixture was serially diluted and plated onto minimal agar $\left[0.2 \%\right.$ glucose, $0.41 \mathrm{mM} \mathrm{MgSO}, 0.1 \%\left(\mathrm{NH}_{4}\right)_{2} \mathrm{SO}_{4}, 0.7 \%$ $\mathrm{K}_{2} \mathrm{HPO}_{4}, 0.2 \% \mathrm{KH}_{2} \mathrm{PO}_{4}, 1.5 \%$ agar], caseinase agar (nutrient broth agar with $1 \%$ Marvel skim milk, $1.5 \%$ agar), or LBA, with appropriate antibiotic selection, and incubated for $48 \mathrm{~h}$ at $25^{\circ} \mathrm{C}$ (D. dadantii and D. solani MK10) or $30^{\circ} \mathrm{C}$ (S39006, S. plymuthica A153). Putative mutants were then tested for acquisition of the full plasmid by patching a selection of colonies onto $\mathrm{LBA}+\mathrm{Tc}$.

\section{Identification of Transposon Insertion Sites by Replicon Cloning}

DNA was extracted from transposon mutants and digested with an enzyme that does not cut within the transposon (See Table 3 for a full list). Digested DNA was purified using an Anachem Spin PCR Clean Up Kit then self-ligated. The ligation mixture was then used to transform E. coli strains CC118 $\lambda$ pir or $\beta 2163$ by heat shock and plated onto LBA (containing DAPA for $\beta 2163$ ) and the appropriate antibiotic. Replicon DNA was subsequently isolated by plasmid extraction and the precise transposon insertion site identified by sequencing using either oREM7 or oREM8 primers.

\section{Identification of Transposon Insertion Sites by RP-PCR}

RP-PCR was conducted largely as previously described (Jacobs et al., 2003; Fineran et al., 2005). Briefly, DNA from transposon mutants was amplified using a two-step PCR process. In the first round, DNA was amplified using a random oligonucleotide mix (oPF106, oPF107, oPF108) and the transposon specific oligonucleotide (See Table 2 for examples). DNA from this reaction was used in a second amplification using oPF109 and a second transposon specific oligonucleotide. The resulting DNA fragments were amplified with the appropriate transposon specific oligonucleotide.

\section{Phenotypic Plate Assays}

D. dadantii mutants were screened on agar plates for production of protease, cellulase, swimming motility, pectate lyase and siderophores as described previously (Cubitt et al., 2013; Monson et al., 2013). Briefly, a normalized number of $D$. dadantii cells was spotted in $10 \mu$ l onto siderophore agar (Schwyn and Neilands, 1987), pectate lyase agar (Pemberton et al., 2005), cellulase agar (Pemberton et al., 2005), gelatinase agar (Burr et al., 2006), caseinase agar (Cubitt et al., 2013), or swimming motility agar (Monson et al., 2013). Swimming plates were incubated for $14 \mathrm{~h}$ and all other plates were incubated at $25^{\circ} \mathrm{C}$ for 2 days. Swimming plates, caseinase plates and siderophore plates required no further development and were analyzed visually. Cellulase, gelatinase and pectate lyase plates were developed appropriately (Cubitt et al., 2013; Monson et al., 2013). Antagonistic activities of bacterial strains against the oomycete, Pythium ultimum and the fungus, Verticillium dahliae, were assayed as described previously (Matilla et al., 2012). 
TABLE 3 | Enzymes that do not cut pDS1028 or pKRCPN1.

\begin{tabular}{|c|c|}
\hline Enzymes & Cut site \\
\hline \multicolumn{2}{|c|}{ Enzymes that do not cut either pDS1028 or pKRCPN1 } \\
\hline Aflll & $C^{\sim} T T A_{\wedge} G$ \\
\hline Apal & $\mathrm{G}_{\wedge} \mathrm{GGCC}^{2} \mathrm{C}$ \\
\hline Avrll & $\mathrm{C}^{\sim} \mathrm{CTAG}_{\wedge} \mathrm{G}$ \\
\hline $\mathrm{BbvCl}$ & $\mathrm{CC}^{\vee} \mathrm{TCA}, \mathrm{GC}$ \\
\hline BstEll & G`GTNAC 、C \\
\hline Fsel & $\mathrm{GG}_{\wedge} \mathrm{CCGG}^{\sim} \mathrm{CC}$ \\
\hline PflFI & GACN`N,NGTC \\
\hline Pmel & GTT ${ }^{2}$ AAAC \\
\hline Pmll & $\mathrm{CAC}^{2}, \mathrm{GTG}$ \\
\hline PspOMl & $\mathrm{G}^{2} \mathrm{GGCC}, \mathrm{C}$ \\
\hline Stul & $A G{ }^{2}, C C T$ \\
\hline Swal & ATTा ${ }^{\sim}$ AAAT \\
\hline Tth1111 & GACN`NANGTC \\
\hline Xmnl & GAANN ${ }_{\text {NNNTTCC }}$ \\
\hline
\end{tabular}

Enzymes that do not cut pKRCPN1 but cut pDS1028

\begin{tabular}{|c|c|}
\hline Ncol & $\mathrm{C}^{\sim} \mathrm{CATG}_{\wedge} \mathrm{G}$ \\
\hline Scal & $\mathrm{AGT}^{\sim}{ }^{\mathrm{A}} \mathrm{ACT}$ \\
\hline Spel & $\mathrm{A}^{\sim} \mathrm{CTAG} \mathrm{N}^{\top} \mathrm{T}$ \\
\hline
\end{tabular}

Enzymes that do not cut pDS1028 but cut pKRCPN1

\begin{tabular}{|c|c|}
\hline Aflll & $C^{\sim} T T A A_{\wedge}, G$ \\
\hline ApaLI & $G^{\sim} T G C A_{\lambda} C$ \\
\hline Bcll & $\mathrm{T}^{\sim} \mathrm{GATC} \wedge \mathrm{A}$ \\
\hline BsrGl & $T^{\sim}$ GTAC $_{\wedge} \mathrm{A}$ \\
\hline BssSI & $C^{\sim} \mathrm{ACG}, \mathrm{G}$ \\
\hline Mlul & $A^{2} \mathrm{CGCG}_{\wedge} T$ \\
\hline Nsil & $A_{\wedge}, T G C A^{\sim} T$ \\
\hline Pcil & $A^{\sim} \mathrm{CATG}_{\wedge} T$ \\
\hline Pvul & $\mathrm{CG}^{\sim}{ }^{\wedge} \mathrm{T}_{\wedge} \mathrm{CG}$ \\
\hline Zral & $\mathrm{GAC}^{\sim}$, GTC \\
\hline
\end{tabular}

\section{Indigoidine Liquid Assay}

Production of indigoidine was assessed in liquid as described previously (Reverchon et al., 2002). Briefly, cells were grown in $\mathrm{PMB}, \mathrm{LB}$, or MM9, pelleted by centrifugation, supernatant samples removed and the cell pellets snap frozen in liquid nitrogen. Cells were thawed on ice, the pellet resuspended in $1 \mathrm{ml}$ dimethyl sulfoxide (Sigma) and vortexed. Cellular debris was pelleted by centrifugation $\left(10000 \mathrm{~g}, 10 \mathrm{~min}\right.$ ) and the $\mathrm{A}_{615}$ of the supernatant measured. Indigoidine levels were expressed as the $\mathrm{A}_{615} \mathrm{OD}_{600}{ }^{-1}$. Where appropriate, a student's $t$-test was used to determine statistical significance of differences between mutants.

\section{Flotation Assay}

Flotation assays of S39006 were carried out as described previously (Ramsay et al., 2011). Briefly, strains were grown in a $30 \mathrm{ml}$ sealed universal plastic tube overnight at $30^{\circ} \mathrm{C}$ in $\mathrm{LB}$.
The following day, a normalized number of cells were used to inoculate a $5 \mathrm{ml}$ culture which was grown for $24 \mathrm{~h}$ on a roller wheel at $30^{\circ} \mathrm{C}$. Cultures were left to settle at room temperature for $24 \mathrm{~h}$.

\section{Microscopy}

Samples were taken directly from liquid culture without further preparation, largely as described previously (Ramsay et al., 2011). Phase contrast light microscopy was undertaken using an Olympus BX-51 microscope with a 100x oil immersion lens. Images were captured using a QICAM camera and QCapture Pro software. Images were cropped and the scale bar added using Adobe Photoshop. All images were representative of those observed for any particular strain.

\section{$\beta$-galactosidase Assay}

$\beta$-galactosidase activity was determined by monitoring the breakdown of $4^{\prime}$-Methylumbelliferyl- $\beta$-D-galactopyranoside (Melford Laboratories). At the indicated time point, samples of liquid culture $(100 \mu \mathrm{l})$ were taken and frozen at $-80^{\circ} \mathrm{C}$ until needed. Samples were thawed and $10 \mu \mathrm{l}$ removed and frozen at $-80^{\circ} \mathrm{C}$ for $15 \mathrm{~min}$ and thawed at $37^{\circ} \mathrm{C}$. Next, $100 \mu \mathrm{l}$ of Reaction Mix (Phosphate-buffered saline, $400 \mu \mathrm{g} \mathrm{ml}^{-1}$ lysozyme, $250 \mu \mathrm{g}$ $\mathrm{ml}^{-1} 4^{\prime}$-Methylumbelliferyl- $\beta$-D-galactopyranoside) was added to the samples and they were monitored in a Gemini XPS plate reader using the following parameters: $360 \mathrm{~nm}$ excitation, $450 \mathrm{~nm}$ emission, $435 \mathrm{~nm}$ cut off, eight reads per well, measured every minute for $30 \mathrm{~min}$. Relative fluorescence units (RFU) per min were calculated during a linear phase of fluorescence increase and were normalized to the $\mathrm{OD}_{600}$ creating an activity measurement of RFU OD $600{ }^{-1}$.

\section{Sequence Information}

The sequences of pKRCPN1 and pDS1028 were deposited in Genbank and given the accession numbers KT991288 and KT991389, respectively.

\section{RESULTS}

\section{The Plasmids pDS1028 and pKRCPN1 are Capable of Mutagenizing Some Gram-Negative Bacteria}

The pDS1028 and pKRCPN1 plasmids were created as described in Materials and Methods. Both plasmids were sequenced and a schematic of them is shown in Figure 1. Though both pDS1028 and pKRCPN1 contain the transposase gene to facilitate transposition, it is not located within the transposon itself. Thus, when the transposon has "hopped" into a chromosomal location, if the plasmid is unable to replicate in this host (all pir ${ }^{-}$strains) a stable insertion will be created. These two systems were then used to isolate gene knockouts or transcriptional gene fusions. Furthermore, as the two transposons contain different antibiotic selections, they can also be used in combination. In addition, a version of this transposon, described by Ramsay and colleagues has been engineered with a uidA cassette in place of the lac $Z$ cassette described in this work (Ramsay et al., 2011). 

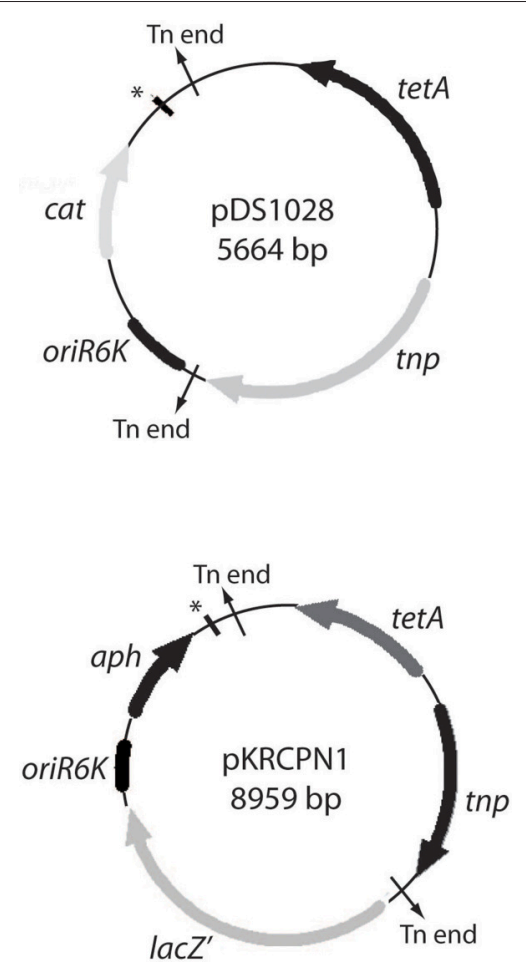

FIGURE 1 | Plasmid maps of pDS1028 and pKRCPN1. Plasmid maps of pDS1028 (top) and pKRCPN1 (bottom) were created. The open reading frames present in each plasmid are indicated as thick arrows with the name adjacent. The transposon ends are indicated with black arrows pointing out of the plasmid. The $\Omega$ fragment is indicated with a thick black line and $\mathrm{a}^{*}$. The length of each plasmid in basepairs (bp) is indicated inside the plasmid.

The utility of pDS1028 and pKRCPN1 was assessed in 20 different bacterial host strains. Different ratios of E. coli donor and recipient cells were tested and putative transposon insertions identified. A tetracycline resistance cassette was encoded in the plasmid backbone of both pDS1028 and pKRCPN1 but not within the transposon. Therefore, in the case of pDS1028, if the full plasmid transferred between the donor and recipient strain, any resulting mutants would be resistant to both chloramphenicol and tetracyline, and any transposon insertions would be resistant to chloramphenicol but sensitive to tetracycline. Of the 20 strains tested using both plasposon systems, putative transposon insertions were observed in 16 strains (Table 4). For each strain where putative transposon insertions were observed, 50 colonies were tested for tetracycline sensitivity. No tetracycline resistant colonies were observed for any strain with successful transposon insertions; therefore we concluded that our mutants were transposon insertions and not the result of plasmid transfer.

We were unable to detect putative transposon insertions in Serratia marcescens MSU97 or the Gram-positive, Bacillus subtilis. We tested for the presence of E. coli donor cells after an $8 \mathrm{~h}$ incubation with $S$. marcescens MSU97 and no donor cells were detected (data not shown). MSU97 produces potent bioactive compounds, potentially killing donor cells during
TABLE 4 | Transposon mutant efficiency.

\begin{tabular}{|c|c|c|}
\hline Test strain & $\begin{array}{c}\text { Optimal ratio } \\
\text { (Donor: Recipient) }\end{array}$ & $\begin{array}{c}\text { Transposon mutant } \\
\text { frequency }\end{array}$ \\
\hline \multirow[t]{5}{*}{ Agrobacterium tumefaciens } & 3: 1 & $<2.63 \times 10^{-9}$ \\
\hline & 2: 1 & $<3.45 \times 10^{-9}$ \\
\hline & 1: 1 & $<2.43 \times 10^{-9}$ \\
\hline & $1: 2$ & $<6.34 \times 10^{-9}$ \\
\hline & $1: 3$ & $<3.88 \times 10^{-9}$ \\
\hline \multirow[t]{5}{*}{ Bacillus subtilis sp 168} & 3: 1 & $<7.34 \times 10^{-8}$ \\
\hline & $2: 1$ & $<1.85 \times 10^{-9}$ \\
\hline & $1: 1$ & $<1.75 \times 10^{-9}$ \\
\hline & $1: 2$ & $<9.18 \times 10^{-8}$ \\
\hline & $1: 3$ & $<2.87 \times 10^{-9}$ \\
\hline Chromobacterium violaceum & $1: 3$ & $3.44 \times 10^{-5}$ \\
\hline Citrobacter freundii & 1: 1 & $2.38 \times 10^{-5}$ \\
\hline Citrobacter rodentium & $1: 1$ & $1.84 \times 10^{-5}$ \\
\hline Dickeya dadantii LA15 & $1: 1$ & $2.33 \times 10^{-5}$ \\
\hline Dickeya dadantii 3937 & $1: 3$ & $5.21 \times 10^{-5}$ \\
\hline Dickeya solani & $1: 3$ & $3.81 \times 10^{-6}$ \\
\hline Enwinia wasabiae & $1: 3$ & $2.59 \times 10^{-5}$ \\
\hline $\begin{array}{l}\text { Pectobacterium atrosepticum } \\
\text { SCRI1039 }\end{array}$ & $1: 3$ & $8.45 \times 10^{-6}$ \\
\hline $\begin{array}{l}\text { Pectobacterium atrosepticum } \\
\text { SCRI1043 }\end{array}$ & $1: 3$ & $9.17 \times 10^{-6}$ \\
\hline Pectobacterium brasiliensis & $1: 3$ & $1.83 \times 10^{-7}$ \\
\hline $\begin{array}{l}\text { Pectobacterium carotovorum } \\
\text { Attn10 }\end{array}$ & $1: 3$ & $3.24 \times 10^{-5}$ \\
\hline $\begin{array}{l}\text { Pectobacterium carotovorum sp } \\
193\end{array}$ & $1: 3$ & $7.87 \times 10^{-7}$ \\
\hline $\begin{array}{l}\text { Pectobacterium carotovorum sp } \\
\text { ATCC39048 }\end{array}$ & $1: 1$ & $1.19 \times 10^{-6}$ \\
\hline Serratia marcescens 12 & $1: 2$ & $6.67 \times 10^{-5}$ \\
\hline Serratia marcescens 274 & $1: 2$ & $3.79 \times 10^{-6}$ \\
\hline Serratia plymuthica A153 & $1: 3$ & $2.36 \times 10^{-5}$ \\
\hline Serratia sp 39006 & $1: 3$ & $2.41 \times 10^{-6}$ \\
\hline \multirow[t]{5}{*}{ Serratia sp. MSU97 } & 3: 1 & $<3.85 \times 10^{-9}$ \\
\hline & $2: 1$ & $<6.28 \times 10^{-9}$ \\
\hline & $1: 1$ & $<2.56 \times 10^{-9}$ \\
\hline & $1: 2$ & $<3.26 \times 10^{-9}$ \\
\hline & $1: 3$ & $<4.95 \times 10^{-9}$ \\
\hline
\end{tabular}

conjugal mating (Matilla et al., 2012). Therefore, the lack of transposon mutants from MSU97 may have been due to killing of the $E$. coli donor strain, making successful conjugation unlikely. We were also unable to detect any transposon insertions in $B$. subtilis, though unlike S. marcescens MSU97, this was not due to donor cell death (data not shown). B. subtilis is a Gram-positive organism and conjugation with the Gram-negative E. coli donor strain was not successful.

In the remaining 17 strains, putative transposon mutants were detected with high frequency in all strains except Agrobacterium tumefaciens using both pKRCPN1 and pDS1028 (Table 4). For almost all strains, the optimal ratio of donor to recipient cells was 1:3 (Table 2). To assess randomness and whether the plasposon system could be used to isolate mutants with particular traits, we 
performed three pilot studies (i) in the plant pathogen D. dadantii strain 3937; (ii) in the enterobacterium S39006; and (iii) in two oocydin A producing strains, the biocontrol rhizobacterium, Serratia plymuthica A153, and the phytopathogen, D. solani MK10. A schematic showing the full model of how transposon mutagenesis was performed, and mutants were identified is shown in Figure 2.

\section{Mutations in the vfm Operon in $D$. dadantii are Defective for Protease Production}

$D$. dadantii 3937 was conjugated with $E$. coli CC118 $\lambda$ pir carrying pDS1028. Following conjugation, transposon insertions were screened on caseinase agar containing chloramphenicol (to select for the presence of the transposon), and casein degradation was assessed by scoring for clearing around colonies. Over 15,000 random transposon insertion mutants were screened for reduced caseinase activity, and 10 mutants were identified. Of these 10 mutants, we chose to continue characterization of two mutants: REM392 and REM394.

The transposon encoded within pDS1028 also contains an origin of replication: oriR6K. As a result, genomic DNA from any transposon mutant can be digested, with a restriction endonuclease that does not cut within the transposon and can then be self-ligated to form a plasmid that will form a replicon in a pir $^{+}$strain. Genomic DNA from REM392 was digested with NsiI, self-ligated, and used to transform E. coli strain CC118 $\lambda$ pir. Using oligonucleotides internal to the transposon, the sequence adjacent to the transposon was identified. By applying this method, we identified an insertion in vfmE (REM392) and $v f m A$ (REM394) that caused reduced caseinase (or protease) production in these strains.

VfmE is a transcriptional regulator of the AraC family and was previously identified as an activator of virulence determinants in D. dadantii (Nasser et al., 2013). We also identified a mutation in $v f m A$, the first gene in one operon of the $v f m$ region, and disrupts the function of five genes: $v f m A, v f m Z, v f m B, v f m C$, and $v f m D$ through polarity (Figure 3). VfmA shares high levels of homology with 3-oxoacyl-acyl-carrier-proteins, a subclass of decarboxylating condensing enzymes that include polyketide synthases, though the full role of this protein has not been studied in D. dadantii (Nasser et al., 2013).

To characterize these mutations further, each mutant was tested for protease, cellulase and pectate lyase production (Figure 3). We also examined siderophore production and swimming motility in each of mutant strains. Swimming motility was reduced in both of the mutants tested (Figure 3G). Protease and cellulase production were also reduced in both mutants. Siderophore production was slightly reduced in both of the mutants tested and we were unable to detect a difference in pectate lyase production between mutant and wild type $D$. dadantii using plate assays (Figure 3).

\section{A Mutation in pecS Results in Production of the Pigment Indigoidine}

During our screen of $D$. dadantii mutants, we also identified a mutant that appeared darker on caseinase plates. $D$. dadantii is known to have the cryptic capacity to produce the blue pigment indigoidine, though not naturally under standard laboratory conditions (Reverchon et al., 2002). On LB agar rather than caseinase agar, REM393 still produced the blue pigment (data not shown) and we concluded that this blue pigment was likely indigoidine and the transposon insertion in this strain led to cryptic activation.

Previous work demonstrated that the transcriptional regulator PecS represses production of indigoidine under standard laboratory growth conditions (Reverchon et al., 2002). Therefore, we examined whether the transposon insertions in this strain was located within pecS. Using RP-PCR, we determined that the transposon insertion within REM393 was located within pecS (Figure 4). Mutations in pecS have been characterized previously (Reverchon et al., 2002), but we wanted to show quantitatively that indigoidine production was activated (or derepressed) in REM393, compared with wild type. Pigment levels were assayed in wild type and REM393 in different growth media. Indigoidine levels in wild type cells were significantly lower than in a pecS mutant. We also tested indigoidine levels in the $v f m A$ and $v f m E$ mutants. In both of these strains, indigoidine levels were significantly less than wild type when grown in PMB media, suggesting a link between the $v f m$ region and indigoidine production.

\section{Identification of a Transcriptional Fusion in gvpA1 in $\mathrm{S} 39006$}

S39006 produces gas vesicles, proteinaceous intracellular organelles that are permeable to gas but not liquids. These organelles facilitate buoyancy in a static water column, allowing cells to colonize the air-liquid interface (Ramsay et al., 2011). Gas vesicles are visible in cells by phase contrast microscopy, as they conglomerate as a light-refractile gas "vacuole" inside the cell. S39006 colonies appear opaque on plates due to the production of gas vesicles and colonies incapable of producing gas vesicles appear translucent. To identify mutants that lack gas vesicles, S39006 was mutagenized using the donor plasposon pKRCPN1 and translucent (presumptive gas vesicle defective) strains were identified. We were particularly interested in identifying transcriptional fusions of the $\beta$ galactosidase gene to gvpA1, the first gene in the primary gas vesicle synthesis operon. Over 5000 colonies were screened and a single translucent colony, containing the transposon $88 \mathrm{bp} 3^{\prime}$ of the gvpA1 translational start site, in the correct orientation to form a transcriptional fusion, was identified (Figure 5A). To confirm that the phenotypes were the result of this transposon alone, mutations were moved into a clean genetic background using the generalized transducing phage $\varphi$ OT 8 followed by phenotypic confirmation in the transductants. $\beta$-galactosidase activity (a proxy for gvpA1 transcription) was monitored throughout growth and showed similar activity to $\beta$-glucuronidase fusions in the same gene that were reported by Ramsay et al. (2011; Figure 5). Thus, the plasposon system produces stable insertions and gene fusions in S39006. 


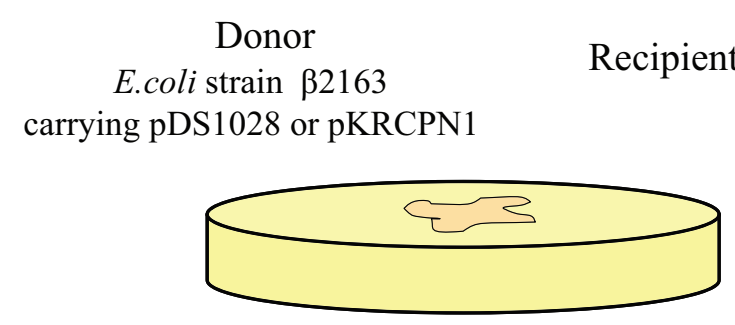

Serial Dilutions of Conjugation Patch
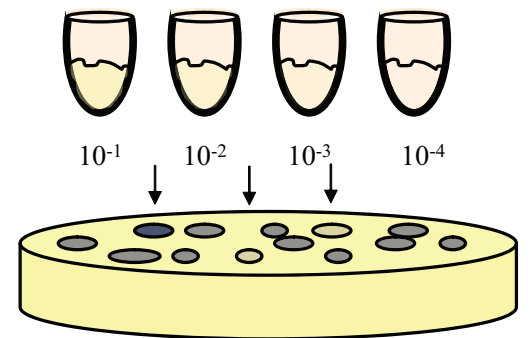

$\mathrm{LBA}+\mathrm{Cm}$ or Kan
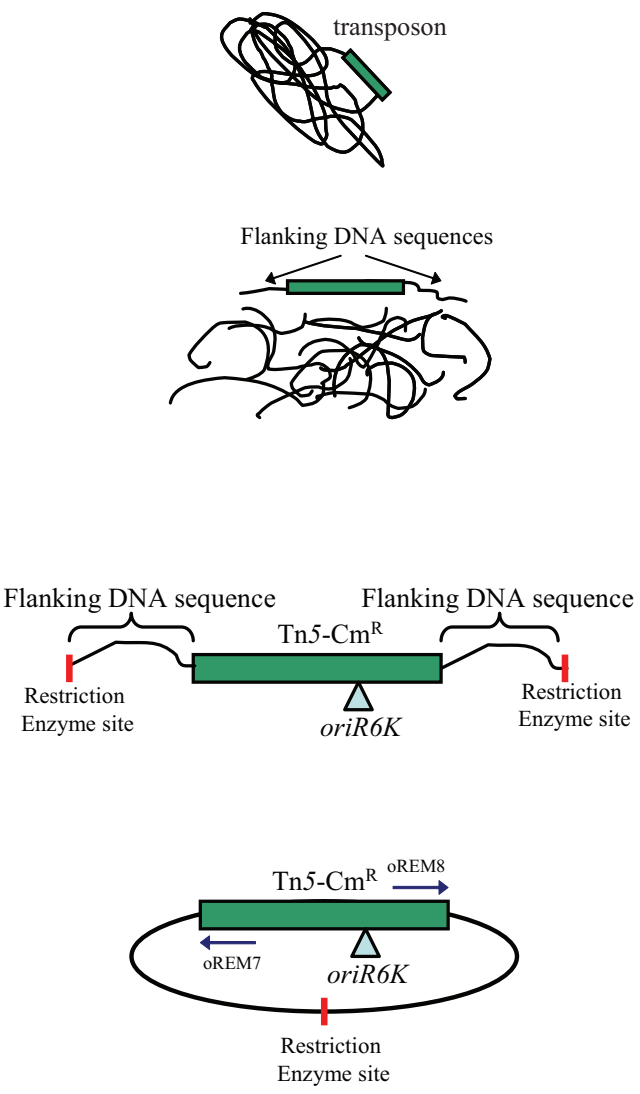

1. Conjugation - Donor and recipient cells were spotted on an LBA + DAPA plate and incubated overnight at $30^{\circ} \mathrm{C}$

2. Selection - Serial dilutions of each mating patch were plated on LBA + selection (either $\mathrm{Cm}$ or $\mathrm{Kn}$ ) to select for recipient cells carrying the transposon

\section{DNA Extraction and Digestion - \\ DNA was extracted from strains and digested with a restriction enzyme that does not cut within the transposon}

\section{Ligation, Transformation and Sequencing - Digested DNA fragments were ligated together and transformed with E. coli strain $\beta 2163$. Plasmid DNA was isolated and sequenced using oligonucleotides oREM7 or oREM8 (pDS1028) or oMAMV1 or oMAMV2 (pKRCPN1)}


A

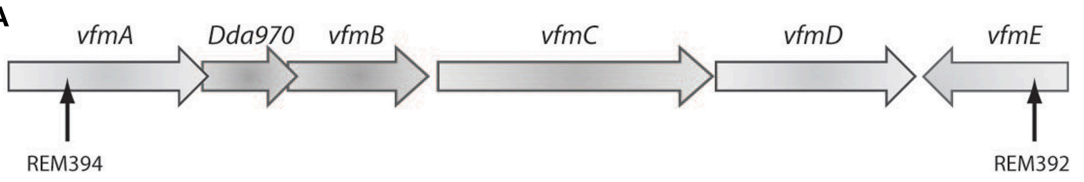

B
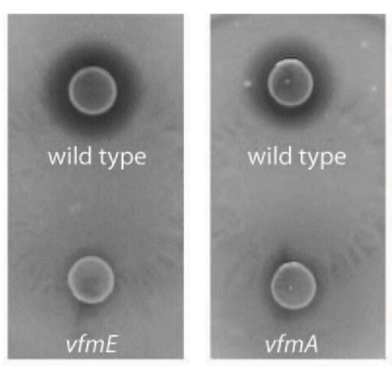

D

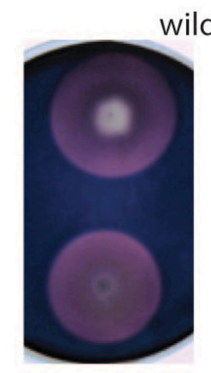

vfmE

$\mathbf{F}$

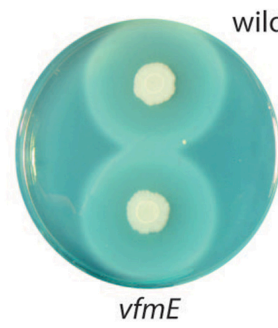

wild type

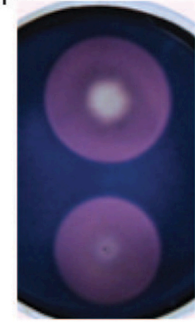

vfmA

C

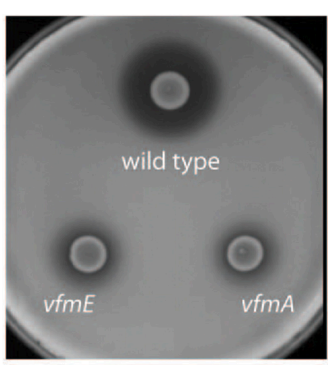

E

wild type

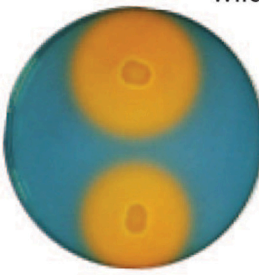

vfmE

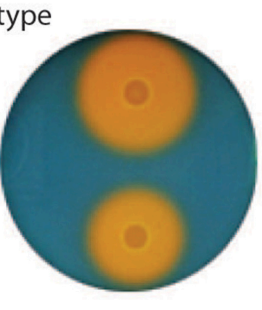

vfmA

G
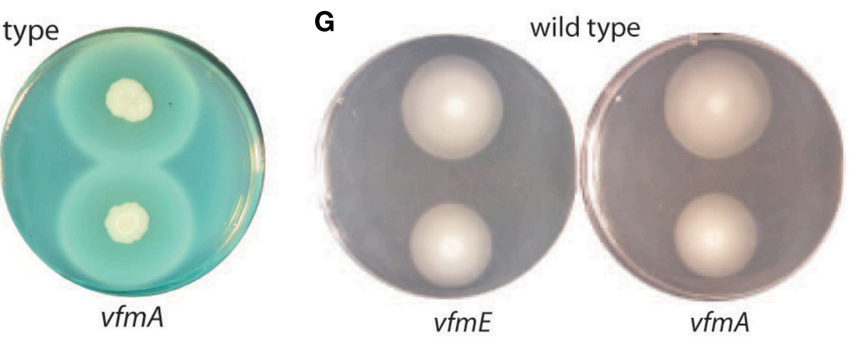

FIGURE 3 | Mutations in the vfm region in D. dadantii. (A) Schematic representation of the vfm cultures in D. dadantii. Genes are represented as open arrows. Black arrows within vfmA and vfmE indicate the sites of the transposon insertion in REM394 and REM392, respectively. Caseinase (B) and gelatinase (C), cellulase (D), siderophore (E), pectate lyase (F), and swimming (G) assay plates comparing wild type and vfmE or vfmA mutants. For each strain, $5 \mu$ l of normalized overnight culture was spotted onto the plate and grown at $25^{\circ} \mathrm{C}$ for $18 \mathrm{~h}$ (swimming) or $48 \mathrm{~h}$ (all other plates). On each plate, the halo surrounding the cell is representative of the enzymatic activity (cellulase and pectate lyase), the siderophores produced or flagellum based swimming.

\section{Mutagenesis of the Oocydin A Gene Clusters in Serratia and Dickeya Strains}

The halogenated haterumalide, oocydin A, was initially isolated from a plant epiphytic bacterial strain due to its strong bioactivity against plant-pathogenic oomycetes (Srobel et al., 1999). However, oocydin A has been also shown to possess antifungal (Thaning et al., 2001), anticancer (Takada et al., 1999), and anti-hyperlipidemic (Sato et al., 2005) properties. Previously, a random transposon mutant library in the oocydin A producing strain, S. plymuthica A153 was constructed and mutants defective in oocydin A production were isolated. We found recently that the ooc gene cluster is widely distributed within the Dickeya genus, including the aggressive phytopathogen D. solani MK10 (Matilla et al., 2015). Here, we employed the plasposon pKRCPN1 to isolate two oocydin A-defective mutants in the phytopathogen D. solani MK10, MK10oocG, and MK10oocN1 (Figures 6A,C). The transconjugant library of MK10 was screened for mutants defective in bioactivities against the plant-pathogenic fungi and oomycete, $V$. dahliae and $P$. ultimum, respectively (Figures 6B,C).

The transducing bacteriophage $\phi \mathrm{XF} 3$ was used to confirm that the observed phenotypes (Figure 6C) were associated with 


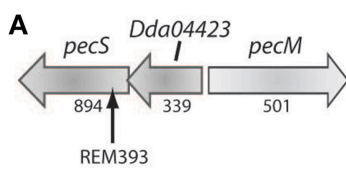

B

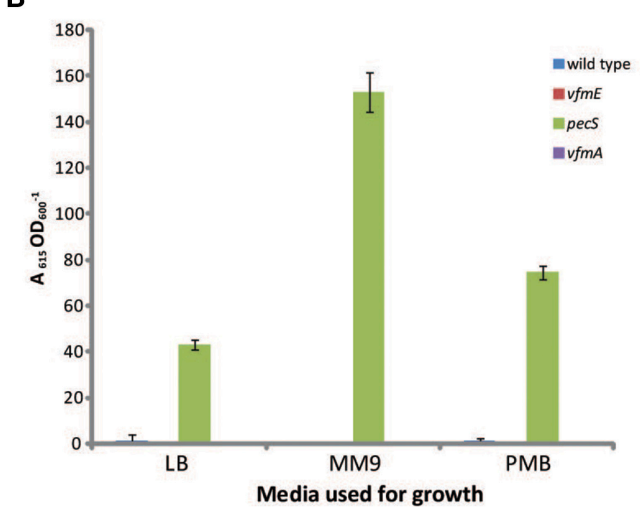

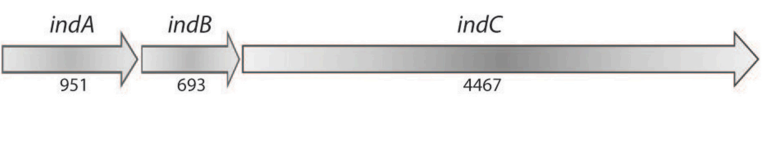

C

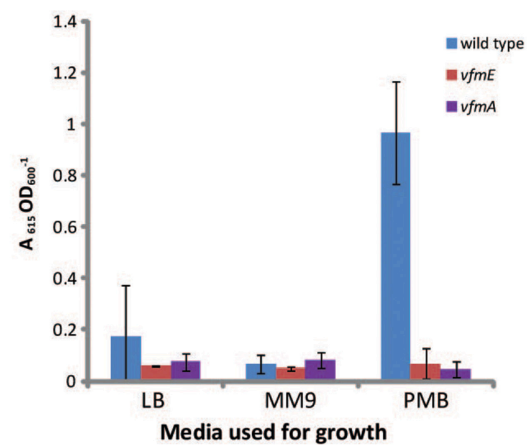

FIGURE 4 | A mutation in pecS overproduces indigoidine. (A) Schematic representation of the pecS and indigoidine biosynthesis genetic cluster in $D$. dadantii. Genes are represented as open arrows and their length in basepairs is indicated below each gene. An arrow indicates the site of the transposon insertion in REM393. (B,C) Indigoidine production in different media. Wild type, vfmE, vfmA, and pecS strains were grown in the indicated liquid media and after $16 \mathrm{~h}$ indigoidine production assayed. Values represent the average of three independent replicates. The data presented in (C) are the same as in (B) but with pecS removed, the scaling reflects this change. Error bars indicate $\pm \operatorname{SD}(n=3)$.

A

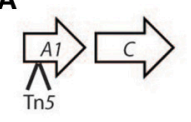
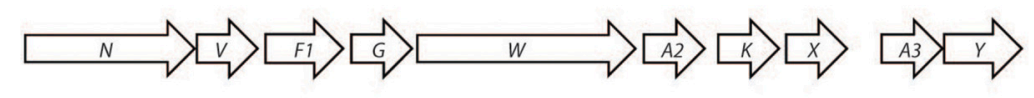

B
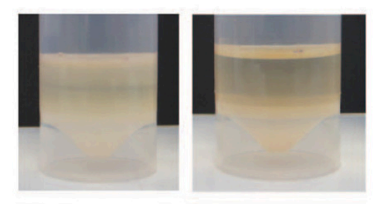

LacA $\operatorname{gvpA1::/acZ}$
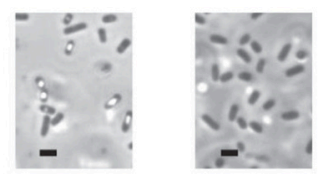

C

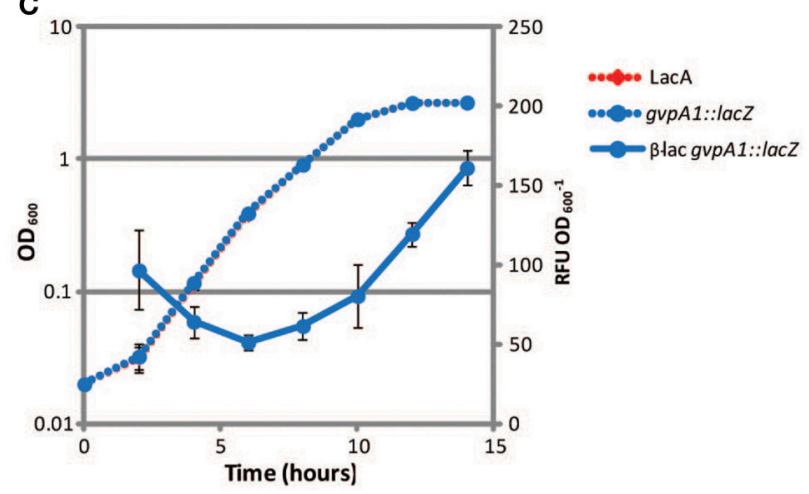

FIGURE 5 | Isolation of a mutant containing a transcriptional fusion in gvpA1 that fails to produce GVs. (A) The genetic organization of the GV operon starting with gvpA1. Each gene within the operon is indicated with an arrow. All gene names have been shortened and "gvp" has been removed. The site of the transposon insertion is indicated with an arrow below gvpA1. (B) Floatation assays of wild type Serratia 39006 and gvpA1 (top) and PCM images of the same cells (bottom). Scale bars indicate $1 \mu \mathrm{m}$. (C) Activity of gvpA1::lacZ fusion throughout growth. Wild type (red dashed) and gvpA1::lacZ (blue dashed) cultures were monitored throughout growth. $\beta$-galactosidase ( $\beta$-lac) activity was determined from samples taken at each time point (blue solid line). Values indicate the average of three independent replicates. Error bars indicate $\pm S D$.

single transposon insertions (Matilla et al., 2014). One of the of the isolated mutants, strain MK10oocG, formed a transcriptional fusion which will allow the study of the expression of the large ooc $J$ - $W$ operon (Figure 6A).

\section{DISCUSSION}

Random transposon mutagenesis has wide ranging usages in many different bacterial systems. This work demonstrates the 

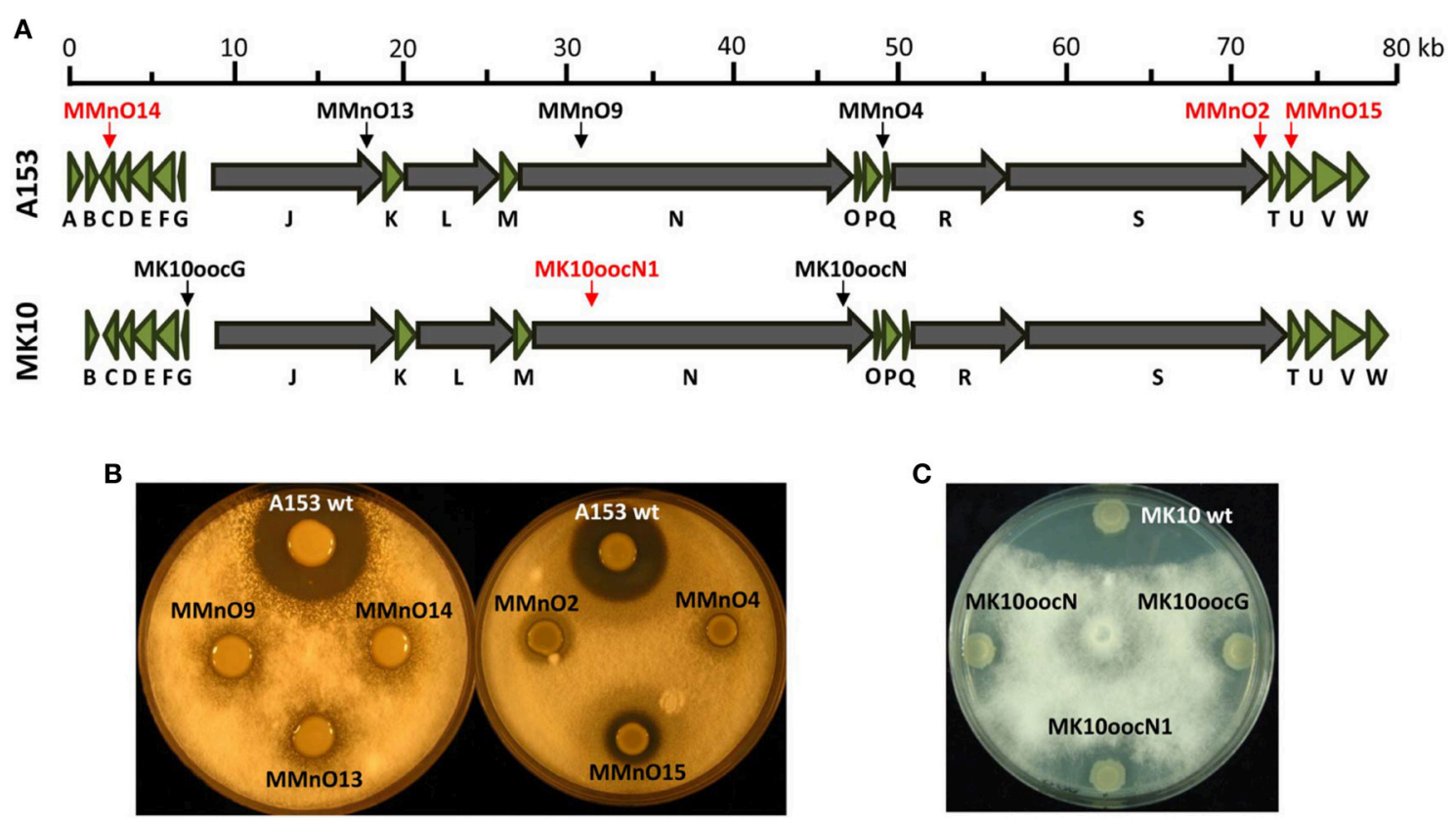

FIGURE 6 | Isolation of oocydin A-defective mutants using the plasposon pKRCPN1. (A) Genetic organization of the ooc biosynthetic gene cluster in Serratia plymuthica A153 and Dickeya solani MK10. Multidomain polyketide synthase genes are shown in gray. Arrows indicate the location of the Tn-KRCPN1 transposon insertions and red arrows indicate that the transposon has been inserted in the right orientation, therefore generating a transcription fusion. The oocA gene is absent from the $00 \mathrm{c}$ gene clusters in all Dickeya strains. (B) Antifungal activity of S. plymuthica A153 strains against Verticillium dahliae. MmnO15 produce none and 3-5\% of the oocydin A wild type levels, respectively (Matilla et al., 2012). (C) Anti-oomycete bioactivities of $D$. solani MK10 strains toward $P$. ultimum. The bioassays were repeated at least three times, and representative results are shown. P. ultimum and $V$. dahliae pictures were taken after 48 and $96 \mathrm{~h}$ of incubation at $25^{\circ} \mathrm{C}$, respectively.

utility of the plasposon system in different hosts, in particular, by creating transcriptional fusions which can be combined together easily. Firstly, we isolated mutants in $D$. dadantii defective in protease production and with cryptic activation of indigoidine production. We also used this system to create a stable transcriptional fusion in $g v p A 1$, the first gene in the gas vesicle cluster of S39006, allowing transcriptional quantification of the gas vesicle operon throughout growth. Finally, we identified mutants in the ooc gene cluster in the phytopathogenic bacterium D. solani MK10.

The plasposon system described in this work is not the first of its kind (Dennis and Zylstra, 1998), but allows any transposon insertion to be identified in two ways, either through what we term "Random Primed PCR" (RP-PCR) or through the creation of a replicon using the origin of replication found within the transposon itself. The use of two different plasposon selection systems allows increased flexibility, e.g., the construction of double mutants, making this a useful resource when engineering targeted mutants. Often one of the most laborious stages of a transposon mutagenesis is the identification of individual insertion sites. The plasposon system described here allows for identification by two different methods, an important feature should any single technique fail to provide a clean answer.

Our pilot studies also yielded interesting results that demonstrated the efficacy of our system. The $v f m$ region of $D$. dadantii has been identified as important for virulence (Nasser et al., 2013). This operon is responsible for production of a new, as yet unidentified, intercellular signal. Here we identified transposon insertion in two of the four transcriptional units comprising the $v f m$ region, $v f m E$, and $v f m A-v f m D$. Tests by Nasser and colleagues showed that mutants defective in both of these transcriptional units showed reduced virulence in the Saintpaulia ionantha (African violet) plant model (2013). We found similar results in our analysis of pectate lyase and protease production in our transposon mutants (though not for cellulase production, where our $v f m E$ and $v f m A$ mutants did not produce significantly less cellulase activity). This may be due to differences in the assays that were used.

The cryptic pigment indigoidine is not expressed under normal laboratory conditions in $D$. dadantii (Reverchon et al., 2002). We identified a mutant (REM393), within pecS, that produced indigoidine. The pecS mutant showed increased pectate lyase activity, cellulase activity and siderophore production. In media containing glycerol as a carbon source (MM9), we saw a significant increase in indigoidine (Figure 4). These observations are consistent with the results of Reverchon et al. (2002) who demonstrated that pecS acts as a repressor of indigoidine.

We also examined indigoidine production in our $v f m A$ and $v f m E$ mutants. Though indigoidine is not normally produced in standard laboratory media, we observed small amounts of production in media containing polygalacturonic acid (PMB), a degradation product of plant cell walls-and perhaps a mimic of in planta conditions. However, in a $v f m A$ or $v f m E$ mutant, no such production was observed, suggesting that the metabolite 
or putative signaling molecule produced from this region may somehow induce indigoidine production in addition to affecting plant virulence (Nasser et al., 2013).

The identification of biosynthetic clusters for different antifungal compounds is of great interest. From previous work, the genetic cluster responsible for production of the halogenated haterumalide, oocydin A, was identified in A153 (Matilla et al., 2012). From bioinformatic analysis, we knew that this cluster was also present in the phytopathogen D. solani MK10. Using the plasposon system, two transposon insertion mutants within the MK10 cluster were identified, one a transcriptional fusion, that could be used to examine transcriptional changes of the cluster under different environmental conditions.

The primary purpose of this study was to construct and determine the general utility of the plasposon system. We believe that these constructs will have wide utility in studies of Gramnegative bacteria. High rates of conjugation were observed in most Gram-negative strains (unless donor killing was a problem). This system will improve functional genomics in Serratia, Pectobacterium, Citrobacter, Dickeya, and Chromobacterium species, but this was a limited repertoire of test hosts. It is very likely that this plasposon system will have far wider utility in taxonomically distant Gram-negative bacteria.

\section{REFERENCES}

Berg, D. E., and Berg, C. M. (1983). The prokaryotic transposable element Tn5. Nat. Biotechnol. 1, 417-435. doi: 10.1038/nbt0783-417

Burr, T., Barnard, A. M., Corbett, M. J., Pemberton, C. L., Simpson, N. J., and Salmond, G. P. (2006). Identification of the central quorum sensing regulator of virulence in the enteric phytopathogen, Erwinia carotovora: the VirR repressor. Mol. Microbiol. 59, 113-125. doi: 10.1111/j.1365-2958.2005. 04939.x

Cordaux, R., and Batzer, M. A. (2009). The impact of retrotransposons on human genome evolution. Nat. Rev. Genet. 10, 691-703. doi: 10.1038/ $\operatorname{nrg} 2640$

Craig, N. L. (1990). P element transposition. Cell 62, 399-402. doi: 10.1016/00928674(90)90001-U

Cubitt, M. F., Hedley, P. E., Williamson, N. R., Morris, J. A., Campbell, E., Toth, I. K., et al. (2013). A metabolic regulator modulates virulence and quorum sensing signal production in Pectobacterium atrosepticum. Mol. Plant Microbe Interact. 26, 356-366. doi: 10.1094/MPMI-09-12-0210-R

Demarre, G., Guerout, A. M., Matsumoto-Mashimo, C., Rowe-Magnus, D. A., Marliere, P., and Mazel, D. (2005). A new family of mobilizable suicide plasmids based on broad host range R388 plasmid (IncW) and RP4 plasmid (IncPalpha) conjugative machineries and their cognate Escherichia coli host strains. Res. Microbiol. 156, 245-255. doi: 10.1016/j.resmic.2004.09.007

Dennis, J. J., and Zylstra, G. J. (1998). Plasposons: modular self-cloning minitransposon derivatives for rapid genetic analysis of gram-negative bacterial genomes. Appl. Environ. Microbiol. 64, 2710-2715.

Evans, T. J., Crow, M. A., Williamson, N. R., Orme, W., Thomson, N. R., Komitopoulou, E., et al. (2010). Characterization of a broad-hostrange flagellum-dependent phage that mediates high-efficiency generalized transiduction in, and between, Serratia and Pantoea. Microbiology 156, 240247. doi: $10.1099 /$ mic. $0.032797-0$

Fineran, P. C., Everson, L., Slater, H., and Salmond, G. P. (2005). A GntR family transcriptional regulator (PigT) controls gluconate-mediated repression and defines a new, independent pathway for regulation of the tripyrrole antibiotic, prodigiosin, in Serratia. Microbiology 151, 3833-3845. doi: $10.1099 /$ mic.0.28251-0

\section{AUTHOR CONTRIBUTIONS}

RM, DS, MM, KR, NW, JR, MW, and GS conceived of the study. RM, DS, MM, KR, ER, NW, and JR designed and performed experiments. AD sequenced the plasmid constructs. $\mathrm{RM}$ wrote the manuscript. RM, AD, MW, and GS edited the manuscript.

\section{ACKNOWLEDGMENTS}

The authors would like to acknowledge several funding sources. DS was supported by a PhD studentship from the BBSRC. Work in the MW lab is supported by the BBSRC (grants BB/G015171/1 and BB/M019411/1). KR was funded by an MRC studentship. RM and the Salmond lab were supported by grants from the BBSRC (Grant No BB/K001833/1). MM was supported by the EU Marie-Curie Intra-European Fellowship for Career Development (FP7-PEOPLE-2011-IEF), grant number 298003. ER was supported by a Harry Smith vacation studentship from the SGM, UK. The authors would also like to thank Ray Chai for careful reading and comments on this manuscript. AD provided technical support. Work with plant pathogens was carried out under DEFRA license No. 50864/197900/1.

Frost, L. S., Leplae, R., Summers, A. O., and Toussaint, A. (2005). Mobile genetic elements: the agents of open source evolution. Nat. Rev. Microbiol. 3, 722-732. doi: 10.1038/nrmicro1235

Grenier, A. M., Duport, G., Pages, S., Condemine, G., and Rahbé, Y. (2006). The phytopathogen Dickeya dadantii (Erwinia chrysanthemi 3937) is a pathogen of the pea aphid. Appl. Environ. Microbiol. 72, 1956-1965. doi: 10.1128/AEM.72.3.1956-1965.2006

Herrero, M., de Lorenzo, V., and Timmis, K. N. (1990). Transposon vectors containing non-antibiotic resistance selection markers for cloning and stable chromosomal insertion of foreign genes in gram-negative bacteria. J. Bacteriol. 172, 6557-6567.

Hökeberg, M., Gerhardson, B., and Johnsson, L. (1997). Biological control of cereal seed-borne diseases by seed bacterization with greenhouse-selected bacteria. Eur. J. Plant Pathol. 103, 25-33. doi: 10.1023/A:1008681608400

Jacobs, M. A., Alwood, A., Thaipisuttikul, I., Spencer, D., Haugen, E., Ernst, S., et al. (2003). Comprehensive transposon mutant library of Pseudomonas aeruginosa. Proc. Natl. Acad. Sci. U.S.A. 100, 14339-14344. doi: 10.1073/pnas.2036 282100

Jimenez, A., and Davies, J. (1980). Expression of a transposable antibiotic resistance element in Saccharomyces. Nature 287, 869-871. doi: 10.1038/287869a0

Larsen, R. A., Wilson, M. M., Guss, A. M., and Metcalf, W. W. (2002). Genetic analysis of pigment biosynthesis in Xanthobacter autotrophicus Py2 using a new, highly efficient transposon mutagenesis system that is functional in a wide variety of bacteria. Arch. Microbiol. 178, 193-201. doi: 10.1007/s00203-0020442-2

Matilla, M. A., Fang, X., and Salmond, G. P. (2014). Viunalikeviruses are environmentally common agents of horizontal gene transfer in pathogens and biocontrol bacteria. ISME J. 8, 2143-2147. doi: 10.1038/ismej.2014.150

Matilla, M. A., Leeper, F. J., and Salmond, G. P. (2015). Biosynthesis of the antifungal haterumalide, oocydin A, in Serratia, and its regulation by quorum sensing, RpoS and Hfq. Environ. Microbiol. 17, 2993-3008. doi: 10.1111/14622920.12839

Matilla, M. A., and Salmond, G. P. C. (2014). Bacteriophage фMAM1, a viunalikevirus, is a broad-host-range, high-efficiency generalized transducer that infects environmental and clinical isolates of the enterobacterial 
genera Serratia and Kluyvera. App. Environ. Microbiol. 80, 6446-6457. doi: 10.1128/Aem.01546-14

Matilla, M. A., Stöckmann, H., Leeper, F. J., and Salmond, G. P. (2012). Bacterial biosynthetic gene clusters encoding the anti-cancer haterumalide class of molecules: biogenesis of the broad spectrum antifungal and antioomycete compound, oocydin A. J. Biol. Chem. 287, 39125-39138. doi: 10.1074/jbc.M112.401026

McClintock, B. (1956). Controlling elements and the gene. Cold Spring Harb. Symp. Quant. Biol. 21, 197-216. doi: 10.1101/SQB.1956.021.01.017

Monson, R., Burr, T., Carlton, T., Liu, H., Hedley, P., Toth, I., et al. (2013). Identification of genes in the VirR regulon of Pectobacterium atrosepticum and characterization of their roles in quorum sensing-dependent virulence. Environ. Microbiol. 15, 687-701. doi: 10.1111/j.1462-2920.2012.02822.x

Nasser, W., Dorel, C., Wawrzyniak, J., Van Gijsegem, F., Groleau, M. C., Deziel, E., et al. (2013). Vfm a new quorum sensing system controls the virulence of Dickeya dadantii. Environ. Microbiol. 15, 865-880. doi: 10.1111/14622920.12049

Pemberton, C. L., Whitehead, N. A., Sebaihia, M., Bell, K. S., Hyman, L. J., Harris, S. J., et al. (2005). Novel quorum-sensing-controlled genes in Erwinia carotovora subsp. carotovora: identification of a fungal elicitor homologue in a soft-rotting bacterium. Mol. Plant Microbe Interact. 18, 343-353. doi: 10.1094/MPMI-18-0343

Prentki, P., and Krisch, H. M. (1984). In vitro insertional mutagenesis with a selectable DNA fragment. Gene 29, 303-313.

Ramsay, J. P., Williamson, N. R., Spring, D. R., and Salmond, G. P. (2011). A quorum-sensing molecule acts as a morphogen controlling gas vesicle organelle biogenesis and adaptive flotation in an enterobacterium. Proc. Natl. Acad. Sci. U.S.A. 108, 14932-14937. doi: 10.1073/pnas.1109169108

Reverchon, S., Rouanet, C., Expert, D., and Nasser, W. (2002). Characterization of indigoidine biosynthetic genes in Erwinia chrysanthemi and role of this blue pigment in pathogenicity. J. Bacteriol. 184, 654-665. doi: 10.1128/JB.184.3.654665.2002

Sato, B., Nakajima, H., Fujita, T., Takase, S., Yoshimura, S., Kinoshita, T., et al. (2005). FR177391, a new anti-hyperlipidemic agent from Serratia. I. Taxonomy, fermentation, isolation, physico-chemical properties, structure elucidation and biological activities. J. Antibiot. 58, 634-639. doi: 10.1038/ja.2005.87

Schwyn, B., and Neilands, J. B. (1987). Universal chemical-assay for the detection and determination of siderophores. Anal. Biochem. 160, 47-56. doi: 10.1016/0003-2697(87)90612-9

Srobel, G., Li, J. Y., Sugawara, F., Koshino, H., Harper, J., and Hess, W. M. (1999). Oocydin A, a chlorinated macrocyclic lactone with potent anti-oomycete activity from Serratia marcescens. Microbiology 145(Pt 12):3557-3564. doi: 10.1099/00221287-145-12-3557

Takada, N., Sato, H., Suenaga, K., Arimoto, H., Yamada, K., Ueda, K., et al. (1999). Isolation and structures of haterumalides NA, NB, NC, ND, and NE, novel macrolides from an Okinawan sponge Ircinia sp. Tetrahedron Lett. 40, 6309-6312. doi: 10.1016/S0040-4039(99)01291-5

Thaning, C., Welch, C. J., Borowicz, J. J., Hedman, R., and Gerhardson, B. (2001). Suppression of Sclerotinia sclerotiorum apothecial formation by the soil bacterium Serratia plymuthica: identification of a chlorinated macrolide as one of the causal agents. Soil Biol. Biochem. 33, 1817-1826. doi: 10.1016/S00380717(01)00109-2

Conflict of Interest Statement: The authors declare that the research was conducted in the absence of any commercial or financial relationships that could be construed as a potential conflict of interest.

Citation: Monson R, Smith DS, Matilla MA, Roberts K, Richardson E, Drew A, Williamson N, Ramsay J, Welch M and Salmond GPC (2015) A Plasmid-Transposon Hybrid Mutagenesis System Effective in a Broad Range of Enterobacteria. Front. Microbiol. 6:1442. doi: 10.3389/fmicb.2015.01442

Copyright (C) 2015 Monson, Smith, Matilla, Roberts, Richardson, Drew, Williamson, Ramsay, Welch and Salmond. This is an open-access article distributed under the terms of the Creative Commons Attribution License (CC BY). The use, distribution or reproduction in other forums is permitted, provided the original author(s) or licensor are credited and that the original publication in this journal is cited, in accordance with accepted academic practice. No use, distribution or reproduction is permitted which does not comply with these terms. 